\title{
Memórias verdadeiras sobre a Vernáculo
}

\author{
Fernando Nicolazzi`
}

Era o tempo do Paulo Renato Souza, ocupante do Ministério da Educação durante longos - demasiado longos - sete anos. A universidade pública no Brasil vivia tempos sombrios, uma espécie de tenebrae aetas perpetrada, curiosamente, por parte dos seus filhos mais diletos. Um processo deliberado de precarização do ensino e das condições da educação brasileira como um todo (e não somente do ensino superior) visava tornar mais rápido o desmantelo da sua dimensão pública, obedecendo a uma cartilha que previa, por razões obtusas, incompreensíveis e inaceitáveis para grande parcela dos envolvidos, a privatização da educação como única saída plausível

Historiador formado pela Universidade Federal do Paraná, professor do Departamento de História da Universidade Federal do Rio Grande do Sul. Este pequeno relato, escrito a partir do amigável convite feito por Hilton Costa, assentase em breves, esparsas e fugidias memórias, ancorando-se em algumas (des)leituras e perspectivas que, se bem me lembro, eram feitas durante meus anos de graduação, momento em que a revista Vernáculo foi fundada e que, de uma forma ou de outra, embasaram minhas intenções em me comprometer com o projeto. De todo modo, sabe-se como o relato memorialístico em tom biográfico traz em si mesmo o signo da ilusão, o que já foi advertido por eminente sociólogo. Reside aí a paráfrase do título, que pretende fazer referência ao texto satírico de Luciano de Samósata, Histórias verdadeiras. O leitor que fique à vontade para formular suas próprias conclusões. 
para a crise universitária. Era o tempo da "privataria tucana", como posteriormente se batizou o movimento.

De forma mais geral, se em outros contextos alguns intelectuais discutiam se o horror era econômico ou político, cá nos trópicos horrorizávamos ainda com a falência de um processo de modernização que, desde há muitas décadas, mostrava-se antes reprodutor do que redutor das desigualdades sociais. Parte da historiografia (se correta em sua avaliação ou não, deixo para os historiadores decidirem) tentava oferecer, com o uso de suas ferramentas eruditas, a resposta que pudesse dar conta de uma explicação possível para tal situação: falava-se, nesse sentido, que nossa modernidade não era lacunar ou deficiente, mas sim que nossa sociedade foi assentada em bases arcaicas, permanecendo ainda sobre este mesmo solo. $\mathrm{O}$ arcaísmo, dizia-se, antes que uma consequência da inépcia nacional, era o impulso propulsor das nossas relações sociais; o arcaísmo era um projeto, o qual remetia às estruturas mais profundas da sociedade luso-brasileira.

Pairava no ar, com uma consistência densa e por vezes insuportável, certo mal-estar na universidade brasileira. No caso mais específico das humanidades, o dilema que se colocava, o qual de uma forma ou de outra ainda se mantém em tempos de ciências sem fronteiras, era criar os mecanismos da sua própria legitimidade, a ponto de Marilena Chauí sugerir à época, criticamente cabe mencionar, a "inessencialidade" das ciências humanas em uma sociedade tecnocrata e neoliberal. O mais triste desta situação é que a própria universidade não encontrava forças diante de um mecanismo 
tão opressor e, por vezes, violento - não apenas física, mas, sobretudo, moralmente violento. Enquanto estudante, minha atenção se voltava para aquilo que estava mais próximo, isto é, o assim chamado "movimento estudantil". E era justamente enquanto estudante que considerava o quão insuficiente era este "movimento" para aqueles que não enxergavam no burocratismo militante as formas adequadas de se portar diante de tal realidade.

O Centro Acadêmico da História lançava, de tempos em tempos, seu fanzine, a voz oficial e oficiosa dos aspirantes à história: O Grito. Alguns alunos com posições heterodoxas e práticas, digamos, libertárias, resolveram fazer frente àquele grupo que, entre outras coisas deveras importante para o "movimento", preocupava-se com o fato de que a classe operária não frequentava a Ilha do Mel (de minha parte, eu sempre suspeitei que ela deixava de frequentar a Ilha, não porque esta fosse elitizada ou burguesa, mas sim por que enjoava na travessia marítima). Por um excesso de criatividade, resolvemos batizar o nosso jornalzinho de... O Berro. E divertíamo-nos implicando com colegas, polemizando com professores, escrevendo poesias, ensaiando análises acadêmicas e, de quando em vez, escrevendo alguma coisa que era lida pelos demais estudantes. Um professor chegou ao ponto de nos definir como "a esquerda festiva" do curso, desconsiderando o fato de que a alusão rodrigueana antes massageava nosso precário ego do que causava qualquer tipo de desconforto.

Daquele anseio por escrever (no fundo, creio que era esta demanda imperiosa pela escrita o que me fazia atuar neste tipo de 
cousa), alguns começaram a se perguntar se tudo não poderia assumir um tom menos jocoso e, assim, tentar tirar proveito daquelas horas passadas na biblioteca, quando o tempo não estava bom ou não havia ninguém para nos desviar do caminho da retidão acadêmica, empurrando-nos ora para o boteco (este singular-coletivo), ora para a cancha do ogrobol. Eis, então, que apareceu, entre a pretensão de seriedade d'O grito e o escracho consciente d'O Berro, outro meio de propagação de ideias, nem tão radical como o primeiro, nem tão avacalhado quanto o segundo; era o jornal Cezariana. De imediato me impressionei com aquilo que me caía sobre as mãos. Daí, em uma conversa de bar, a primeira centelha encontrou o graveto seco: surgiu a proposta de juntarmos esforços e ideias para lançarmos uma revista voltada para a publicação de textos acadêmicos elaborados pelos próprios alunos da graduação, concedendo pequeno espaço (permissivos que éramos!) a um artigo de pós-graduando que porventura se dispusesse a descer do altar. Como tudo que nasce no bar gera bons frutos, a Vernáculo veio à luz, motivada pelo prazer da escrita que movia todos os seus organizadores, com o auxílio financeiro da universidade e também com a solidariedade, infelizmente rara, de um livreiro daqueles que não se fazem mais: o Eleoterio Burrego.

Para o lançamento, fomos presenteados com uma fala da Ana Maria Burmester, pois era também o tempo da professora Ana Burmester, mestre e amiga de todos nós. Meus caminhos e descaminhos pela historiografia são plenamente devedores daquelas aulas maravilhosas, onde aprendíamos não tanto sobre o que estava 
nos livros, mas sim sobre o que fazer com aquela miríade de leituras e vivências sem as quais nos sentíamos órfãos; e não falo aqui apenas dos grandes tratados teóricos sobre a epistemologia da história, mas, sobretudo, daquilo sem o qual um bom historiador é tão somente um bom historiador: a literatura e o cinema, paixões inegáveis de Ana.

O convite feito pelo Hilton Costa para escrever este relato, sinal antes de amizade do que de qualquer importância que estas palavras possam assumir, desde o primeiro momento me deixou em crise existencial, causada pelo medo de talvez esquecer algum episódio, situação ou pessoa importante nessa história toda. Enfim, acabei esquecendo muitos episódios, situações e pessoas, mas tive a oportunidade de me lembrar também de muita coisa e, mais do que tudo, lembrar-me da amizade que motivou tudo isso. Acabei também por remexer alguns arquivos e encontrar lá as palavras que proferi no discurso de formatura, escritas há pelos menos uma década atrás. Dizia então naquela época: "há uma beleza particular neste curso: a paixão que nele move as pessoas, que cria uma verdadeira resistência ao fluxo da degradação, quase uma desobediência ao status quo, que apesar da falta de condições morais e materiais, faz a universidade respirar, faz prosseguir o ensino e a pesquisa e que, enfim, faz a história continuar". Certamente, caso eu tentasse reescrevê-las hoje, os termos seriam distintos (já não é mais o tempo do Paulo Renato!). De qualquer forma, penso que o essencial se mantém e desejo à nova 
geração que retoma corajosamente esta empreitada grandes momentos, como aqueles que tive a oportunidade de vivenciar entre o gosto pelo trabalho e o prazer das amizades, vivenciados na dimensão pública de uma universidade federal.

Sinceramente, não sei se tudo se passou da maneira como aqui foi relatado (depois que me disseram que a história não é memória, acabei por esquecer muitas coisas... embora desconfie também que aquelas "práticas libertárias" tenham porção de culpa neste involuntário esquecimento), mas, até o ponto em que um historiador está autorizado a emitir um juízo sobre fatos passados, creio que, se não "tal como efetivamente se passou”, essas memórias mais ou menos (re)inventadas estão próximas do que este personagem-autor pensava naqueles tempos, sombrios e instigantes tempos. 